J. AMER. SOc. Hort. ScI. 119(2):367-373. 1994.

\title{
Genetic Transformation of Peach Tissues by Particle Bombardment
}

\author{
Xiaojian Ye ${ }^{1}$ and Susan K. Brown \\ Department of Horticultural Sciences, Cornell University, New York State Agricultural Experiment \\ Station, Geneva, NY 14456 \\ Ralph Scorza and John Cordts \\ U.S. Department of Agriculture-Agricultural Research Service, Appalachian Fruit Research Station, \\ Kearneysville, $W V 25430$ \\ John C. Sanford \\ Department of Horticultural Sciences, Cornell University, New York State Agricultural Experiment \\ Station, Geneva, NY 14456
}

\begin{abstract}
Additional index words. Prunus persica, biolistics, particle gun, gene gun, microprojectile bombardment
Abstract. Physical and biological parameters affecting the efficiency of biolistic transformation of peach were optimized using B-glucuronidase (GUS) as a reporter gene, such that efficiency of transient GUS expression in peach embryo-derived callus was increased markedly. Transient expression was also obtained in embryonic axes, immature embryos, cotyledons, shoot tips, and leaves of peach. Stable expression of a fusion gene combining neomycin phosphotransferase (NPTII) and B-glucuronidase activities has been achieved in peach embryo calli. Sixty-five kanamycin-resistant callus lines were obtained from 114 pieces of bombarded calli after 4 months of selection. Nineteen of the 65 putative transformant lines produced shoot-like structures. Seven lines were examined to confirm stable transformation using the colorimetric GUS assay and PCR analysis. All seven lines showed GUS activity. PCR analysis confirmed that, in most of the putative transformants, the chimeric GUS/NPTII gene had been incorporated into the peach genome. The transgenic callus lines were very weakly morphogenic, presumably because the callus was 5 years old and no transgenic shoots developed from this callus. Results of this research demonstrate the feasibility of obtaining stable transgenic peach tissue by biolistic transformation.
\end{abstract}

Peach (Prunus persica L. Batsch.) is an important fruit crop of the temperate zone, the worldwide production of which exceeded 6.6 million $t$ in 1988 (USDA, 1988). The goal of most peach breeding programs is to combine traits such as desirable time of maturity, resistance to biotic and abiotic stress factors, desirable tree growth habit, and improved fruit quality. Although conventional breeding has been productive, it remains time-consuming and expensive. The ability to manipulate individual horticultural characteristics within an established cultivar would be advantageous.

Advances in genetic transformation and their application with tissue culture and plant regeneration schemes provide a new approach for breeders seeking to improve cultivars. Successful gene transformation has been reported for numerous plant species. However, only a few woody perennials have been transformed and regenerated successfully; i.e., poplar, walnut, several Prunus sp., Rubus, and apple (Filatti et al., 1987; Graham et al., 1990; James et al., 1989; Laimer da Camara Machado et al., 1992; Mante et al., 1989; McGranahan et al., 1988; Smigocki and Hammerschlag 1991). Agrobacterium-mediated gene transfer has been the primary means of transformation in most cases.

Biolistic transformation has been used successfully to deliver

Received for publication 18 Mar. 1993. Accepted for publication 19 July 1993. This research was funded through a USDA-Cornell Univ. cooperative agreement. Appreciation goes to Martin Goffinet for his assistance and expertise in microtechnology. Appreciation is also extended to William Crosby, Plant Biotechnology Institute, Saskatoon, Sask., Canada, for supplying plasmids pBI505 and pBI426. From a thesis submitted by X.Y. in partial fulfillment of the requirements for the MS degree. The cost of publishing this paper was defrayed in part by the payment of page charges. Under postal regulations, this paper therefore must be hereby marked advertisement solely to indicate this fact.

${ }^{1}$ Graduate student. Present address: Biology Dept., Dartmouth College, Hanover, NH 03755.
DNA into various plant species, including maize, rice, wheat, barley, and soybean (Creissen et al., 1990; Kartha et al., 1989; Klein et al., 1988a; 1988b; McCabe, et al., 1988a; Wang et al., 1988;). Stable transformation has also been demonstrated in soybean (Christou et al.,1987, 1989; McCabe et al., 1988b), tobacco (Klein et al., 1988c; Tomes et al., 1990), maize (Klein et al., 1989), cotton (Finer and McMullen, 1990), and papaya (Fitch et al., 1990). The biolistic production of fertile transgenic corn plants (Fromm et al., 1990; Gordon-Kamm et al., 1990) has ended a decade of unfruitful attempts by many scientists. For difficult-toregenerate tree fruit cultivars, the biolistic process offers the opportunity for meristem transformation, which would facilitate regeneration. Reported here is the optimization of the biolistic transformation process in peach tissues and successful introduction and stable expression of foreign genes in peach embryo callus using particle bombardment.

\section{Materials and Methods}

Plant materials. Peach embryo callus cultures were derived 5 years prior to the experiment from immature (40- to 50-day postbloom) embryos isolated from fruit of open-pollinated seedlings of a red leaf peach breeding selection (14DR60), following the general methods of Hammerschlag et al. (1985). These long-term embryo calli were growth regulator-independent, produced embryos and shoot-like structures, but formed true shoots at a very low rate (Scorza et al., 1990). The embryo calli were maintained by putting six to eight pieces of callus $(\approx 5 \times 5 \mathrm{~mm})$ on DriverKuniyuki-Walnut medium (DKW) (McGranahan et al., 1987) that

Abbreviations: GUS, B-glucuronidase; NPTII, neomycin phosphotransferase; PCR, polymerase chain reaction 
contained $2 \mathrm{mg} \cdot \mathrm{liter}^{-1}$ thiamine. $\mathrm{HCl}, 100 \mathrm{mg} \cdot \mathrm{liter}^{-1}$ myo-inositol, 1 mg.liter ${ }^{-1}$ nicotinic acid, $0.01 \mathrm{mg} \cdot$ liter $^{-1}$ indole-3-butyric acid, 2 mg.liter ${ }^{-1}$ glycine, $1 \mathrm{mg} \cdot$ liter $^{-1}$ 6-benzylaminopurine, 30,000 mg. liter ${ }^{-1}$ sucrose, and $0.25 \%$ gelrite. The $\mathrm{pH}$ was adjusted to 5.8 using $\mathrm{KOH}$ and $\mathrm{HCl}$. Calli were cultured at $24 \mathrm{C}$ under a $16-\mathrm{h}$ photoperiod provided by continuous fluorescent light at $40 \mu \mathrm{mol} \cdot \mathrm{m}^{-2} \cdot \mathrm{s}^{-1}$, with transfers at 2-week intervals. One day prior to bombardment, freshly subcultured calli were cut into pieces (5-mm squares). Ten pieces were distributed in a circle with a $4.5-\mathrm{cm}$ diameter in the center of a $100 \times 15-\mathrm{mm}$ petri dish that contained $30 \mathrm{ml}$ of DKW medium.

To test the effect of subculturing frequency on transformation efficiency, peach embryo calli were subcultured for 2 months at various intervals (3 days and 1, 2, 3, 4, and 6 weeks) after bombardment.

Open-pollinated peach seeds from the cultivar Lovell (Lawyer Nursery, Plains, Mo.) were stored at $4 \mathrm{C}$ for 30 days. The endocarps were cracked open and the seeds removed and washed under running tap water for $30 \mathrm{~min}$, then soaked in water overnight. Seeds were then disinfected for $2 \mathrm{~h}$ in $1 \%$ sodium hypochlorite with a few drops of Tween 20, and rinsed three times with sterile distilled water for $15 \mathrm{~min}$. The seed coat was removed and the embryonic axis was isolated from the attached cotyledons. Leaf primordia surrounding the apical meristem were removed to expose the meristematic dome. The medium used for growing embryonic axes consisted of half-strength MS salts (Murashige and Skoog, 1962), $100 \mathrm{mg} \cdot \mathrm{liter}^{-1} i$-inositol, $0.4 \mathrm{mg} \cdot \mathrm{liter}^{-1}$ thiamine. $\mathrm{HCl}, 0.5 \mathrm{mg} \cdot$ liter $^{-1}$ nicotinic acid, $0.5 \mathrm{mg}$ liter ${ }^{-1}$ pyridoxine. $\mathrm{HCl}, 20,000 \mathrm{mg} \cdot$ liter $^{-1}$ sucrose, and $0.25 \%$ gelrite, adjusted to $\mathrm{pH}$ 5.8. Ten dissected embryonic axes (average size $2.5 \mathrm{~mm}$ ) were placed in the center of a $100 \times 15-\mathrm{mm}$ petri dish containing $30 \mathrm{ml}$ of medium such that they covered an area of $3 \mathrm{~cm}^{2}$. The radicle ends were embedded in the medium and the apical meristem exposed to the accelerated microprojectiles. They were cultured subsequently at $24 \mathrm{C}$ with a 16 -h photoperiod provided by continuous fluorescent light at $40 \mu \mathrm{mol} \cdot \mathrm{m}^{-2} \cdot \mathrm{s}^{-1}$.

Osmotic effects on transformation efficiency were tested on peach embryonic axes by supplementing the bombardment medium with equal ratios of mannitol and sorbitol at combined concentrations of $0,0.25,0.5,0.75,1.0,1.25$, and $1.5 \mathrm{M}$.

Mature open-pollinated seeds of the peach rootstock 'Nemaguard' (Lawyer Nursery) were stored and disinfected in the same way as described for the embryonic axes. The culture medium was the same as that of Mante et al. (1989) for immature cotyledons, except that $2.5 \mu \mathrm{M}$ IBA and $12.5 \mu \mathrm{M}$ TDZ were used. Ten cotyledons with the embryonic axes removed were arranged for bombardment by pointing the axis end towards the center of the plate with the cotyledon orientated ad- or abaxial to the medium solidified with $1 \%$ TC agar.

Immature embryos were excised from 'Lovell' peach seeds at $\approx 60$ days after bloom. Ten embryos $(6 \mathrm{~mm}$ average size with cotyledons attached to embryo axis) were oriented with embryo axis facing upward in MS medium solidified with $0.7 \%$ TC agar, covering a $7-\mathrm{mm}^{2}$ area in the center of a $100 \times 15-\mathrm{mm}$ petri plate.

Shoot tips were excised from actively growing mature orchard trees at the New York State Agricultural Experiment Station. Following sterilization, the apical meristems were exposed by leaf primordia removal. Ten explants $(0.5$ to $1.0 \mathrm{~cm})$, with the apical meristem facing upward, were placed on MS medium on a $100 \times$ $15-\mathrm{mm}$ petri dish covering an area of $4 \mathrm{~cm}^{2}$.

Young, expanding leaves ( $\approx 3$ to $5 \mathrm{~cm}$ in length), along with their petioles, were collected from field plants at the New York State Agricultural Experiment Station. Following sterilization, the leaf margins, tip, and base were cut off, and the remainder of the leaf was cut using a paper punch to produce uniform leaf discs $5 \mathrm{~mm}$ in diameter, with each disc bisected by the leaf midrib. Ten leaf discs were placed in the center of a $100 \times 15-\mathrm{mm}$ petri plate with their abaxial side up on MS medium.

Plasmid DNA. B-glucuronidase (GUS) and neomycin phosphotransferase (NPTII) were the two markers used in this study. They served as screenable and selectable markers for transient and stable selection, respectively. The plasmid pBI505 (supplied by William Crosby, Plant Biotechnology Institute, Saskatoon, Sask., Canada) is a derivative of pUC9 plasmid, with a GUS gene driven by a double $35 \mathrm{~S}$ cauliflower mosaic virus promoter plus a leader sequence from alfalfa mosaic virus (Datla et al., 1990). The GUS gene is followed by the 3' non-coding region of the nopaline synthase (NOS) gene. Plasmid pBI426 has the same promoter as pBI505, except that the GUS gene is fused (Datla et al., 1990) with the NPTII gene, conferring resistance to kanamycin (Beck et al., 1982) so that GUS expression and kanamycin resistance are genetically coupled. The plasmid pUC118 (Viera and Messing, 1987) lacking both GUS and NPTII was used in all experiments as a negative control.

All plasmids were amplified in Escherichia coli strain DH5F' and prepared using a cesium chloride-ethidium bromide gradient.

Microprojectile coating with DNA. Except where noted, M10 tungsten particles (Sylvania, GTE Products Corp, Towanda, Pa.), which have a mean diameter of $1.0 \mu \mathrm{m}$, were used as microprojectiles. The plasmid DNA was coated onto the microprojectiles using $\mathrm{CaCl}_{2} /$ spermidine precipitation as described by Smith et al. (1992). About $500 \mu \mathrm{g}$ of tungsten coated with $0.8 \mu \mathrm{g}$ of DNA was used to bombard each plate.

To test the effect of DNA concentration on transformation efficiency, the amount of DNA in the DNA-M10 particle precipitation mixture was varied from 0.4 to $1.6 \mu \mathrm{g}$ for each bombardment.

Microprojectile bombardment. Bombardment was performed using a helium-driven biolistic device. It is a retrofit of the gunpowder device. Detailed information about this system is provided by Sanford et al. (1991a). In this study, two launch mechanisms - helium entrainment and the flying disc- — were used. In using the helium entrainment mechanism, microprojectiles were loaded onto a nylon mesh $(2.4 \mathrm{~cm}$ in diameter, $94 \mu \mathrm{m}$ thick) that was placed in the path of the shock wave. After the target samples were in place, the sample chamber was evacuated to 0.3 atm and the high-pressure chamber was pressurized with helium. When the pressure overlaying the membranes exceeded their combined strength, the membranes ruptured, resulting in a shock wave. This shock wave entrained and accelerated the particles directly as it passed through the nylon mesh. In using the flying disc mechanism, microprojectiles were loaded onto a Kapton membrane $(2.4 \mathrm{~cm}$ in diameter, 2 mil thick) that transected the shock wave in the same position as the nylon mesh. Upon firing, the Kapton macroprojectile was launched by the resultant shock wave and was accelerated until it was stopped by a steel screen placed 1 $\mathrm{cm}$ from the macroprojectile launch site. Upon impact, microprojectiles were launched and accelerated toward the samples. Bombardment using the gunpowder-driven device (PDS-1000, Dupont Co. Wilmington, Del.) (Sanford et al., 1987) was also performed for comparison.

In preliminary experiments, different combinations of helium pressure, gap distance (distance from power source to macroprojectile), and target distance (distance from microprojectile launch site to biological target) were tested on transformation efficiency of peach embryonic axes using flying disc and helium 
entrainment configuration. No significant differences on transformation efficiency were observed among treatments (data not shown). Except where noted, the flying disc configuration with the combination of 8.3 MPa pressure, 0.7- $\mathrm{cm}$ gap distance, and $5.5-\mathrm{cm}$ target distance was used for all the bombardments.

The effect of a helium flush to reduce gas resistance was tested with peach embryonic axes using both M5 $(0.77 \mu \mathrm{m}$ in diameter $)$ and M10 tungsten particles at a 1.1-cm gap distance, $11.5-\mathrm{cm}$ target distance, and 8.3-MPa pressure. The vacuum chamber was flushed with helium for $10 \mathrm{~s}$ during evacuation before bombardment.

After bombardment, all petri plates were sealed with Parafilm and incubated at $24 \mathrm{C}$ under light. Two days following bombardment, either a transient assay was performed or the tissues were transferred to selective medium.

In all experiments, at least three replicate petri plates were bombarded per treatment.

Detection of GUS expression. The activity of the GUS enzyme was detected using the histochemical assay described by Jefferson (1986, 1987a). Two days following bombardment, the samples were transferred into a 24-well plate and immersed in the GUS staining mixture (McCabe et al., 1988b). The plate was sealed with Parafilm and incubated overnight at 37C. GUS-expressing cells were detected microscopically by the distinct blue color that developed within their interior as a result of the enzymatic cleavage of 5-bromo-3-chloro-3-indolyl-b-D-glucuronic acid (X-gluc). To score the GUS activity, explants were scanned individually under the microscope. Very often, clusters of blue cells were observed and were counted as a single event. Transformation efficiency was expressed as the number of blue spots per petri plate.

Histological study of particle penetration. Peach cotyledons were examined to address the question of particle penetration because this tissue is firm and easy to handle. Gold particles (1.7 $\mu \mathrm{m}$ in diameter) were used to bombard peach cotyledons. Tissues showing expression following X-gluc staining were fixed and paraffin-embedded according to the procedure of Meyerowitz (1987). An Olympus System microscope (BHS model) with interference contrast and polarized light was used to scan sections for GUS-positive cells and to localize the gold particles.

Selection of stable transformants. To obtain stable transformants, peach embryo calli were tested as the regenerative materials. Plasmid pBI426 was used as a selective marker that encodes GUS/ NPTII fusion protein conferring resistance to kanamycin and GUS activity. Peach embryo calli were incubated at $24 \mathrm{C}$ for $48 \mathrm{~h}$ following bombardment. They were then transferred to freshly made DKW medium containing $150 \mathrm{mg} \cdot$ liter $^{-1}$ of kanamycin and incubated for 3 weeks, followed by selection on $20 \mathrm{mg} \cdot$ liter $^{-1}$ of G418 (geneticin). They were subcultured every 3 weeks.

PCR analysis. DNA was isolated from peach embryo calli derived from 5-month-old transgenic callus lines and from calli bombarded with pUC118 following the method of Doyle and Doyle (1990). Polymerase chain reaction (PCR) (Saiki et al., 1985) was performed according to the manufacturer's instructions (Perkin-Elmer Cetus) using 1 to $2 \mu \mathrm{g}$ of the isolated plant DNA (or $0.1 \mu \mathrm{g}$ of plasmid pBI426 as a positive control) and one pair $(1 \mu \mathrm{g}$ of each) of the primers in a total reaction volume of $100 \mu$ l. The primers were 5'd(TGTGGAATTGATCAGCGTTGGTGGGGAAAGCGCG) and 5'd(CACCGAAGTTCATGCCAGTCCAGCG) complementary to the 5'- and 3'-coding region of the GUS gene, respectively, for the amplification of the GUS gene. A PCR cycle consisted of a denaturation step at $92 \mathrm{C}$ for $1.5 \mathrm{~min}$, an annealing step at $60 \mathrm{C}$ for $1.5 \mathrm{~min}$, and an extension step at $72 \mathrm{C}$ for $3 \mathrm{~min}$, for a total of 30 cycles. After amplification, $20 \mu \mathrm{l}$ of each sample were electrophoresed on a $1.4 \%$ agarose gel and the PCR-amplified fragments were visualized by ethidium bromide staining.

\section{Results and Discussion}

Comparison of transformation efficiencies of peach embryo calli using the gunpowder-vs. the helium-driven system. An experiment was conducted to test the relative transformation efficiencies of peach embryo callus using the new helium- vs. the gunpowder-driven system. Transformation efficiencies for helium entrainment and flying disc were three and five times that of the gunpowder device, respectively (Table 1). With the gunpowder device, most of the blue cells were concentrated on a few pieces, whereas with the helium-driven system, the transformed blue cells were distributed on many pieces of calli, indicating an improved particle dispersion pattern.

Effect of helium flush on transformation efficiency of peach embryonic axes. The gas surrounding the target sample can affect biolistic transformation by slowing microprojectiles when they pass through the gas, or by transmitting a potentially damaging shock wave. Usually the gas is removed with a vacuum pump by drawing a vacuum of ( 94.8 to $98.2 \mathrm{kPa})$. However, there is always some residual gas left surrounding the biological sample. Using a light gas, such as helium, instead of air as a residual gas can reduce gas resistance (Smith et al. 1992). In two experiments (Fig. 1), M10 particles consistently yielded a comparable number of transformants with and without the helium flush, suggesting no difference between treatments. However, when smaller M5 particles were used, the bombardment with helium flush yielded three times as many blue cells as without helium flush. This result is consistent with what is seen in bacteria, where a helium flush increases transformation efficiency 5- to 6-fold for M5 particles, but only 2-fold for the larger M10 particles (Smith et al., 1992). The difference in response to a helium flush between M10 and M5 particles indicates that smaller particles are influenced more by the residual gas surrounding the target sample. This is not difficult to understand, because the smaller the particle is, the more rapid the deceleration. Using smaller particles together with a helium flush may result in DNA delivery efficiency comparable to larger particles, but with less cell injury (smaller holes). This may lead to higher rates of stable transformation.

Effect of DNA concentration on transformation efficiency of peach embryonic axes and embryo calli. At the low DNA concentration $(0.4 \mu \mathrm{g})$, transformation efficiency was lower in both embryonic axes and embryo calli (Fig. 2). As the DNA concentration increased to $0.8 \mu \mathrm{g}$, transformation efficiency increased, with about double and triple the number of GUS-expressing cells

Table 1. Comparison of transformation efficiency on peach embryo calli using the helium- vs. gunpowder-driven system.

\begin{tabular}{lcccr}
\hline Configuration & $\begin{array}{c}\text { Pressure } \\
(\mathrm{MPa})\end{array}$ & $\begin{array}{c}\text { Gap distance }^{\mathrm{z}} \\
(\mathrm{cm})\end{array}$ & $\begin{array}{l}\text { Target dis- }^{\text {Tance }}(\mathrm{cm}) \\
\text { tafficiency }^{\mathrm{y}}\end{array}$ \\
\hline Helium entrainment & 8.3 & 0.7 & 5.5 & $129.0 \pm 28.0$ \\
Flying disc & 8.3 & 0.7 & 5.5 & $206.0 \pm 32.9$ \\
& 8.3 & 1.4 & 5.5 & $188.0 \pm 48.2$ \\
Gunpowder & & & & $41.0 \pm 15.9$ \\
\hline
\end{tabular}

${ }^{\mathrm{z}}$ Gap distance is defined as the distance from power source to macroprojectile.

y Target distance is defined as the distance from microprojectile launch site to biological target.

${ }^{x}$ Transformation efficiency is expressed as the number of blue spots per plate. Each plate was bombarded once. Data represent a mean value ( \pm SE) of five replicates. 


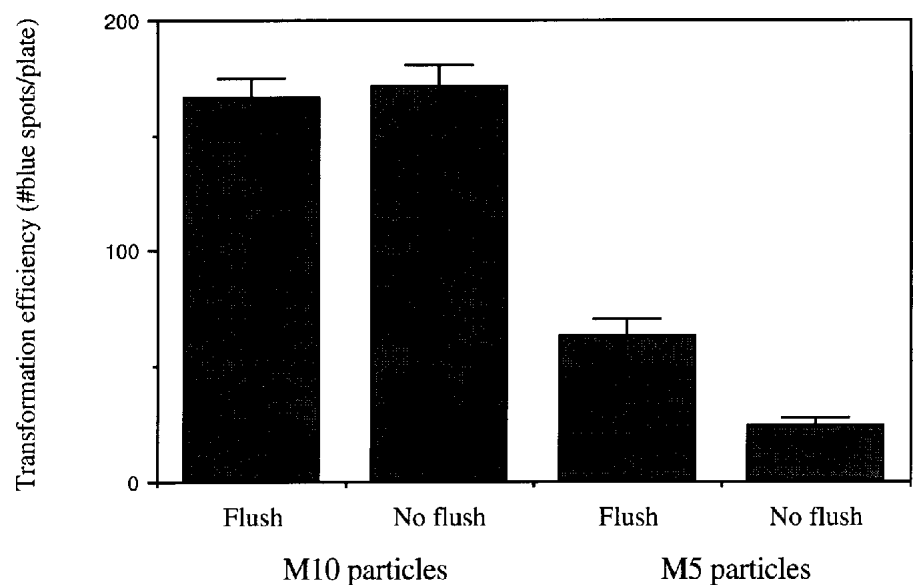

Fig. 1. Effect of helium flush on transformation efficiency of peach embryonic axes using helium-driven biolistic device. Data represent mean values ( \pm SE) of two experiments, each with three replicates.

detected in embryonic axes and embryo calli, respectively. GUS expression reached a maximum at this concentration and stayed roughly at this level even with increased DNA concentrations. Further increases in DNA concentration above the standard concentration of $0.8 \mu \mathrm{g}$ per bombardment did not result in an increased number of transformants, which is consistent with results in $E$. coli (Smith et al., 1992). Smith and coworkers also found that as little as $0.2 \mu \mathrm{g}$ DNA per bombardment produced consistently more transformants than the standard quantity of $0.8 \mu \mathrm{g}$ DNA in three of four experiments. Klein et al. (1988b) noticed severe aggregation of particles caused by the addition of high concentrations of DNA, resulting in inefficient DNA delivery. However, the increased degree of particle aggregation may not be the result of increased DNA concentration per se. Although DNA is prepared from $\mathrm{CsCl}$ gradients in most cases, a considerable amount of protein is still present, which causes the particle agglomeration. An increased degree of particle agglomeration may occur as a result of increased DNA concentration, primarily because the amount of protein is also increased. Therefore, it may be necessary to use higher-purity DNAs free of protein contaminants (i.e., extra phenol extractions) if higher concentrations of DNA are desired. In fact, increased rates of transformation have been observed with increased DNA concentrations of up to 3 to $4 \mu \mathrm{g}$ per bombardment using very pure DNA (H. Daniell, personal communication).

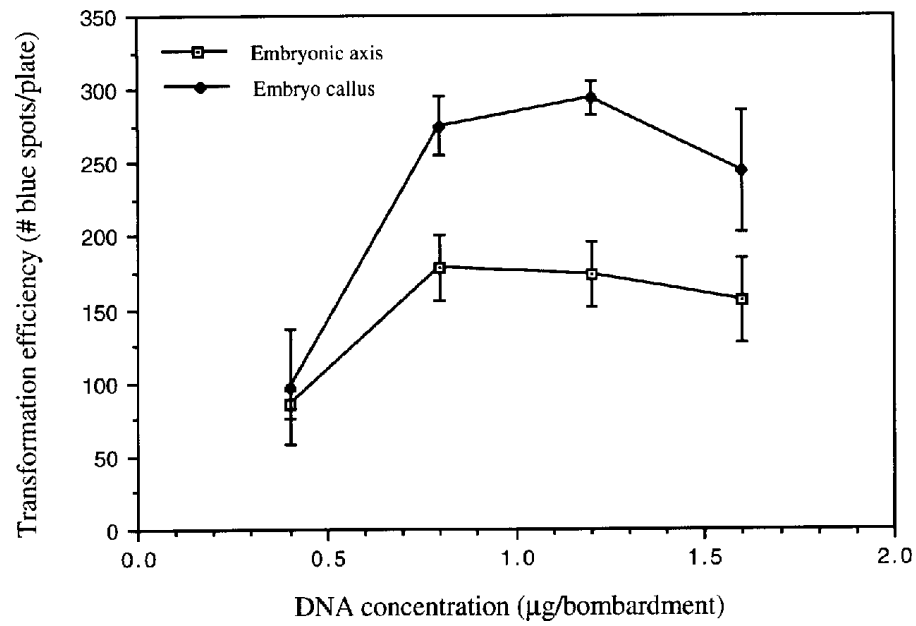

Fig. 2. Effect of DNA concentration on transformation efficiency of peach embryonic axes and embryo calli. Data represent a mean value $( \pm \mathrm{SE})$ of four replicates for each experiment.

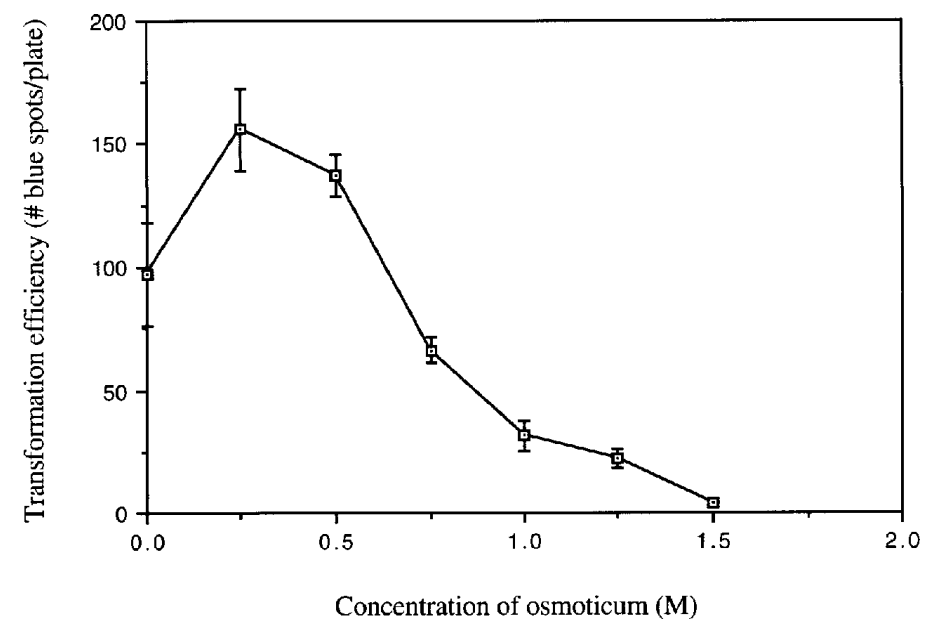

Fig. 3. Effect of osmoticum on transformation efficiency of peach embryonic axes. Data represent mean values $( \pm \mathrm{SE})$ of two experiments, each with three replicates.

Effect of osmoticum on transformation efficiency of peach embryonic axes. The number of blue cells increased when either 0.25 or $0.5 \mathrm{~m}$ osmoticum was added to the medium (Fig. 3). However, addition of $0.75 \mathrm{~m}$ osmoticum produced fewer transformants than the control. Further increases in osmoticum continued to cause decreased transformation efficiency and finally brought the level of GUS expression down to nearly zero at $1.5 \mathrm{M}$. To define the optimal osmoticum concentration further, an experiment was performed by varying the concentration of osmoticum from 0 to $0.7 \mathrm{M}$ in 0.1-M increments (Fig. 4). As the concentration of osmoticum increased, the number of blue cells increased, until it reached a maximum near $0.3 \mathrm{M}$. At this concentration, the number of blue cells was doubled compared to the control. The beneficial effect of incorporating osmoticum in the bombardment media has also been observed in yeast (Armaleo et al., 1990), E. coli (Smith et al., 1992), Bacillus (Shark et al., 1991), tobacco suspension cells (Russell et al., 1992), and tobacco chloroplasts (Ye et al., 1990), although the optimal concentration for these species varies greatly, ranging from 0.25 to $1.75 \mathrm{M}$. Osmotic adjustment in the bombardment medium is believed to be responsible for stabilization of the cell membranes for better healing of the lesions caused by particle penetration, and reduction of turgor pressure in the target cells, thus reducing cytoplasmic leakage and cell rupture.

Effect of subculture frequency on transformation efficiency of peach embryo calli. Highest rates of transformation were obtained

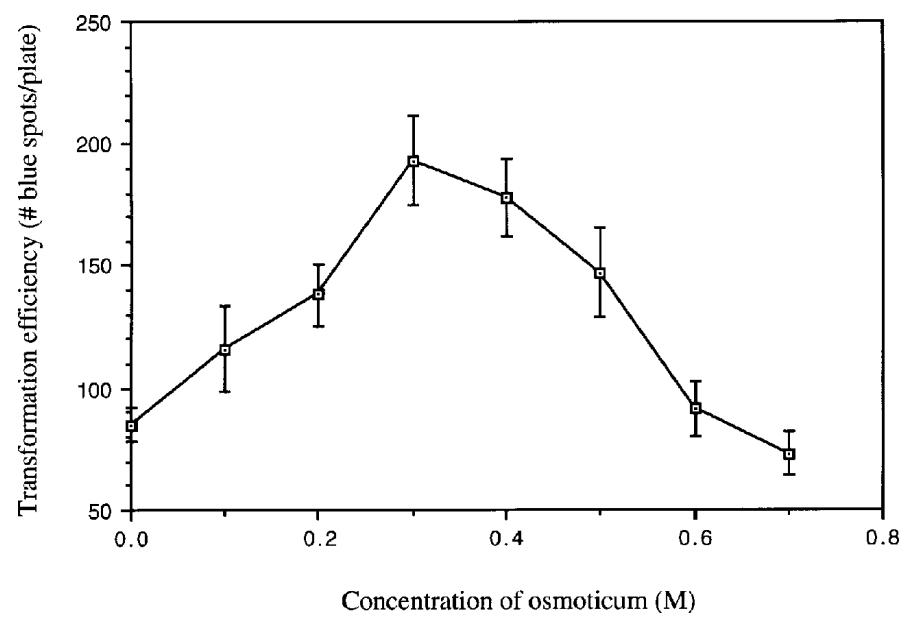

Fig. 4. Effect of osmoticum concentration on transformation of peach embryonic axes. Data represent mean values $( \pm \mathrm{SE})$ of two experiments, each with four replicates. 
when calli were subcultured more frequently, at intervals of between 3 days to 2 weeks (Fig. 5). The number of transformants declined dramatically when calli were subcultured at prolonged intervals; i.e., 3 weeks or longer. For calli subcultured at 3- or 4-week intervals, transformation efficiency was reduced by half. A further decrease in transformation efficiency was observed when calli were subcultured at 6-week intervals, where the transformation efficiency was only one-sixth that of the 2-week interval. Cell age and physiological stage are known to have an important effect on transformation efficiency. In bacteria and yeast, cells from early $\log$ and stationary phase, respectively, are transformed most efficiently (Shark et al., 1991; Smith et al., 1992). For tobacco suspensions, cells bombarded 4 days after subculture yielded the highest rate of transformation (Russell et al., 1992), while cells 6 days or older produced a much lower number of transformants. The decrease in transformation efficiency for calli with longer subculture intervals may be attributed to: the depletion of nutrients in the culture medium necessary for active cell division and growth; or accumulation of metabolites or toxic substances. When subcultured at prolonged (4- or 6-week) intervals, some calli started to turn brown, indicating the accumulation of phenolic compounds in the cell. Generally, healthy and actively dividing cells are most receptive to biolistic transformation. When subjected to bombardment conditions, cells undergo severe stresses imposed by a high vacuum, the impact of particles, acoustic shock, gas blast, and cellular penetration. Only healthy cells can tolerate and survive such stresses. Calli subcultured frequently have a higher percentage of healthy cells; hence, they have the potential to produce more transformants.

Transient GUS expression in different peach tissues following biolistic transformation. The helium-driven device with flying disc configuration was used to transform other peach tissues, including immature embryos, shoot tips, and leaves. Because peach materials were not all available at the same time, transformation efficiencies for each tissue type could not be compared in one experiment. Results from each independent experiment are summarized in Table 2. Relatively high levels of GUS activity were detected in all tissue types tested, except for peach shoot tips. These rates are probably underestimations because, in most cases, the whole surface area of the sample was stained, making it impossible to count each individual blue spot. As a result, a stained area (ablue spot) was considered to be a single transformant. While

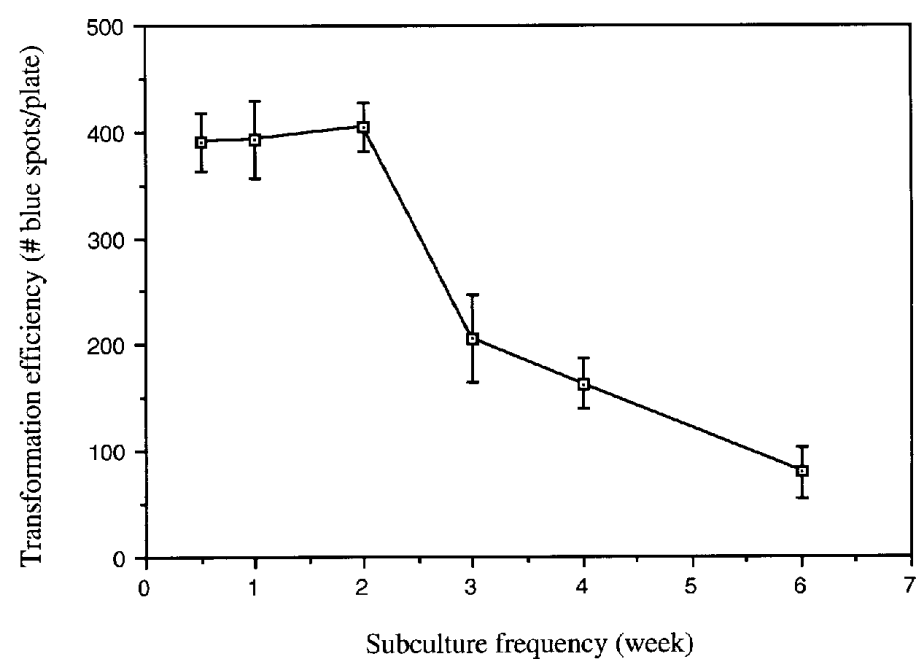

Fig. 5. Effect of subculture frequency on transformation of peach embryogenic calli. Data represent mean values $( \pm \mathrm{SE})$ of two experiments, each with three replicates.
Table 2. Transient expression of GUS in different peach tissues. ${ }^{\mathrm{z}}$

\begin{tabular}{lc}
\hline \hline Tissue & Efficiency $^{\mathrm{y}}$ \\
\hline Embryo callus (10 calli/plate) & $731 \pm 57.1$ \\
Embryonic axis ${ }^{\mathrm{x}}(10$ axis/plate) & $531 \pm 44.2$ \\
Cotyledon $(10$ cotyledons/plate) & $622 \pm 54.3$ \\
Immature embryo $(10$ embryos/plate) & $228 \pm 31.3$ \\
Leaf disc (10 discs/plate) & $465 \pm 20.9$ \\
Shoot tip (10 tips/plate) & $98 \pm 7.4$
\end{tabular}

${ }^{\mathrm{z}}$ Samples were bombarded with 1.0- $\mu \mathrm{m}$ gold particles coated with plasmid pBI505. Helium-driven biolistic device was used with the flying disc configuration at $8.3 \mathrm{MPa}$ pressure, $0.7 \mathrm{~cm}$ gap distance, and $5.5 \mathrm{~cm}$ target distance. Each plate was bombarded twice.

yTransformation efficiency is expressed as the number of blue spots per plate. Data represent a mean value $( \pm \mathrm{SE})$ for two experiments, each with five replicates.

${ }^{\mathrm{x}}$ Osmoticum $(0.3 \mathrm{M})$ was incorporated in the bombardment medium.

${ }^{w}$ Due to the tender nature of immature embryos, only one bombardment was performed for each plate.

the bombardment conditions were optimized for peach embryo calli and embryonic axes, these conditions may not be optimal for these other peach tissues. If higher transformation rates are needed for these tissues, a simple series of optimization experiments can be carried out, as described by Sanford et al. (1991b).

The ability to transform peach embryo calli, embryonic axes, and cotyledons is significant because regeneration from these tissues has been reported (Hammerschlag et al., 1985; Mante et al., 1989; Scorza et al., 1990a). These tissues might be prime targets for future studies aimed at delivery of selectable markers through the biolistic process. High transformation rates of leaf discs were also achieved by the biolistic process. However, at present, there is no report showing regeneration from field-grown peach leaves. Efficient leaf tissue culture and regeneration systems need to be developed before leaf material can be used to obtain transgenic peach.

Genetic transformation will be especially useful if genes can be transferred to peach cultivar cells from mature peach plantlets that can be regenerated. The foreign gene expression observed in shoot tips in this study may be a first step towards this goal. Although the transformation efficiency in shoot tips was not very high (penetration might be a limiting factor due to the firmness and small cell size of this material), further studies may provide a suitable approach to genetic improvement of peach clones.

Histological studies of particle penetration. Particles were always localized within blue cells. Particle penetration was limited to the first, second, or third cell layer, with an average of two to three particles in each cell. Some cells contained up to 10 particles. Although some particles were observed in the second and third cell layers, most particles were found inside the epidermal cells.

It is probable that particle penetration beyond the epidermal cell layer is necessary to obtain stable transformation in many regeneration systems. Therefore, more violent treatments (such as higher pressure, shorter gap distance, and short target distance) may be needed to give better particle penetration.

Selection of stable transformants. The optimization of biolistic transient transformation provided a base for subsequent stable transformation studies because high levels of transient expression is generally a prerequisite for recovery of stable transformants. The embryo calli became necrotic after 2 months in culture on selective medium. However, fragile kanamycin-resistant calli started to emerge from previously necrotic tissues bombarded with pBI426 and were evident after 3 months in culture. These calli continued to proliferate on the selective medium and grew into 
discrete pieces of callus. Each callus was maintained as an individual line. From about 114 pieces of bombarded callus (six explants/plate), 65 resistant lines were recovered after 4 months. This represents an average of three resistant lines per bombardment. Of the 65 putative transformant lines, 19 produced shoot-like structures. An estimate of the transient-to-stable conversion frequency was made by comparing the average number of cells expressing GUS transiently to the average number of resistant callus lines obtained per bombardment. In the same experiment described above, three plates were included for transient GUS assays ( 2 days after bombardment) and yielded an average of 180 blue spots per plate. Thus, $\approx 2 \%$ of the transient transformants were converted to stable transformants. As high as a $10 \%$ transient-tostable conversion frequency has been reported for tobacco suspension cells with the same plasmid (Russell et al., 1992), although conversion rates are more typically $1 \%$ to $2 \%$. Unlike intact tissues, the tobacco suspension cells can be spread uniformly on the surface of filter papers, which provides a significantly larger surface area for bombardment. Moreover, each transformed suspension cell can give rise to a stable colony. Selection of stable transformants from intact tissues is more difficult. A few calli (six out of 66) were also produced from the necrotic tissues bombarded with microprojectiles coated with plasmid pUC118 (as a negative control). However, these calli had very slow and limited growth compared to those bombarded with $\mathrm{pBI} 426$. Continuous growth of calli on selective medium after 5 months suggested that the putative $\mathrm{pBI} 426$ transformants were stables. To confirm that these kanamycin-resistant callus lines were stable transformants, a portion of the calli from seven vigorously growing, pBI426-transformed callus lines, plus one line bombarded with pUC118, were selected for further GUS assay and PCR analysis.

GUS assay of putative transformants. All the kanamycinresistant lines (1 to 7) exhibited GUS activity, whereas calli bombarded with pUC118 (8) had no detectable GUS activity. Although the GUS-positive lines showed similar levels of resistance to kanamycin (based on the degree of callus proliferation), the level of GUS expression seemed to vary, with lines 1,2,3, and 7 expressing GUS most strongly. GUS expression was evident after only 30 min of incubation, presumably because most or all of the cells in the calli were expressing GUS activity.

PCR analysis of transgenic calli. Five callus lines produced the expected 1.6-kb fragment (Fig. 6; lanes 2, 4, 5, 6, and 8), which is identical to that amplified from plasmid pBI426. No DNA of similar size was amplified from callus bombarded with pUC118 (lane 9). Surprisingly, no similar fragment was observed in callus lines 2 and 6 (lanes 3 and 7, respectively), even though GUS activity was detected in these lines. These two lines may have had rearrangements or mutations in the GUS sequence, thus disrupting the PCR process.

At least three lines of evidence support that the fusion gene coding for GUS and NPTII was stably integrated and expressed in peach embryogenic callus cells: 1) the ability of the callus lines to grow vigorously on kanamycin medium; 2) demonstration of GUS enzymatic activity in kanamycin-resistant callus lines; and 3) specific amplification of the introduced genes from the transformed cell lines. These results demonstrate the feasibility of obtaining stable transgenic peach embryogenic callus using the biolistic process. Attempts to regenerate plants from the transformed callus have been unsuccessful. Although shoot-like structures were observed from the transformed calli, shoot production never occurred, due to the loss of regeneration ability of these longterm embryo calli.

Different peach tissues can be transformed using the biolistic

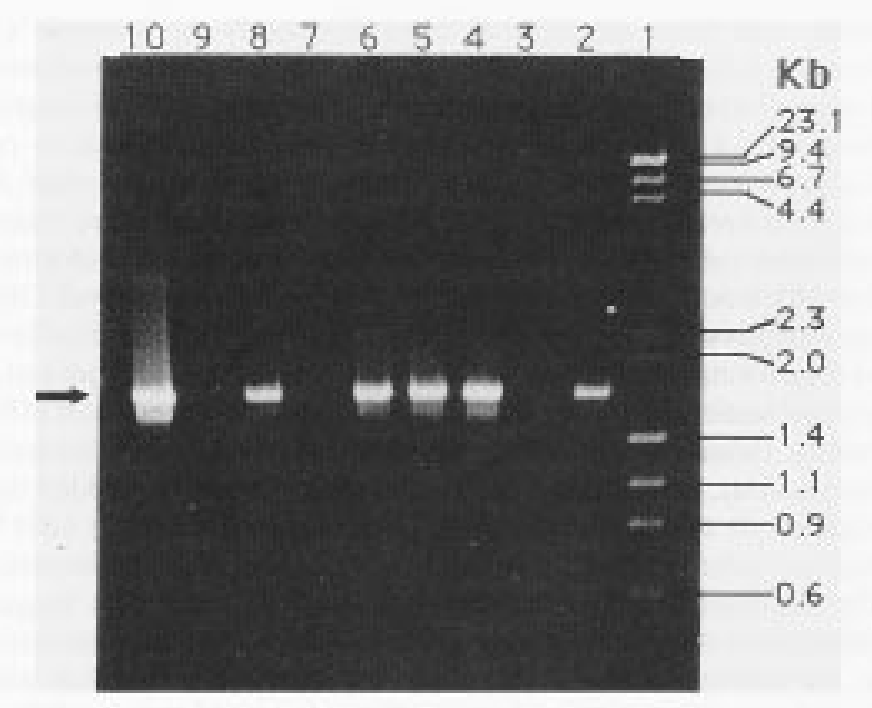

Fig. 6. PCR amplification of GUS gene from transgenic peach embryogenic calli. DNAs isolated from callus tissues were used for PCR amplification using the primers that recognized the 5'- and 3'- coding region of the GUS gene, respectively. The arrow indicates the amplified GUS fragment. Lane 1: $\varnothing$ X174 RF DNA HaeIII fragments/1 HindIII fragments. Lanes 2 to 8: DNAs from seven transgenic calli.Lane 9: DNA from callus bombarded with pUC118 (as a negative control). Lane 10: plasmid pBI426 DNA (as a positive control).

process. By optimizing various parameters, relatively high efficiencies of DNA delivery have been achieved in different peach tissues, including embryogenic calli, embryonic axes, immature embryos, cotyledons, and leaves. Transient gene expression in a number of peach tissues indicates the potential of using such tissues to obtain stable transformants. The ability to stably transform peach embryo callus shows that it should be possible to obtain transgenic peach plants. The development of more-efficient regeneration systems using clonal (not embryonic) tissue sources will be very helpful for the application of genetic transformation for peach improvement.

\section{Literature Cited}

Armaleo, D., G.N. Ye, T.M. Klein, K.B. Shark, J.C. Sanford, and S.A. Johnston. 1990. Biolistic nuclear transformation of Saccharomyces cerevesiae and other fungi. Curr. Genet. 17:97-103.

Beck, E., G. Ludwig, W.A. Awerswald, B. Reiss, and H. Schaller. 1982. Nucleotide sequence and exact location of the neomycin phosphotransferase gene from transposon Tn5. Gene 19:324-336.

Christou, P., D.E. McCabe, and W.F. Swain. 1987. Stable transformation of soybean callus by DNA-coated gold particles. Plant Physiol. 87:671674

Christou, P., W.F. Swain, N.S. Yang, and D.E. McCabe. 1989. Inheritance and expression of foreign genes in transgenic soybean plants. Proc. Natl. Acad. Sci. USA 86:7500-7504.

Creissen, G., C. Smith, R. Francis, H. Reynolds, and P. Mullineaux. 1990. Agrobacterium and microprojectile-mediated viral DNA delivery into barley micro-derived cultures. Plant Cell Rpt. 8:680-683.

Datla, R.S., J.K. Hammerlindl, L.E. Pelcher, G. Selvaraj, and W.L. Crosby. 1990. A bi-functional gene fusion between neomycin phosphotransferase and B-glucuronidase: A broad spectrum genetic marker for plants. J. Cell. Biochem. Suppl. 14E:279. (Abstr.)

Doyle, J.J. and J.L. Doyle. 1990. Isolation of plant DNA from fresh tissue. Focus 12:13-15.

Filatti, J.J., J. Selmer, B. McCown, B. Haissig, and L. Comai. 1987. Agrobacterium-mediated transformation and regeneration of Populus. Mol. Gen. Genet. 206:192-99.

Finer, J.J. and M.D. McMullen. 1990. Transformation of cotton (Gossypium hirsutum L.) via particle bombardment. Plant Cell Rpt. 8:586-589.

Fitch, M.M., R.M. Manschardt, D. Gonsalves, J.L. Slightom, and J.C. 
Sanford. 1990. Stable transformation of papaya via microprojectile bombardment. Plant Cell Rpt. 9:189-194.

Fromm, M.E., F. Morrish, C. Armstrong, R. Williams, J. Thomos, and T.M. Klein. 1990. Inheritance and expression of chimeric genes in the progeny of transgenic maize plants. Bio/Technology 8:833-839.

Gordon-Kamm, W.J., T.M. Spencer, M.L. Spencer, T.R. Adams, R.J. Daines, W.G. Start, J.V. O’Brein, S.A. Chamber, W.R. Adams, Jr. N.G. Willetts, T.B. Rice, C.J. Mackey, R.W. Krueger, A.P. Kausch, and P.G. Kausch. 1990. Transformation of maize cells and regeneration of fertile transgenic plants. Plant Cell 2:603-618.

Graham, J., R.J. McNicol, and A. Kumar. 1990. Use of the GUS gene as a selectable marker for Agrobacterium-mediated transformation of Rubus. Plant Cell Tissue Organ Cult. 20:35-39.

Hammerschlag, F.A., G. Bauchan, and R. Scorza. 1985. Regeneration of peach plants from callus derived from immature embryos. Theor. Applied Genet. 70:248-251.

James, D.J., A.J. Passey, D.J. Barbara, and M. Bevan. 1989. Genetic transformation of apple (Malus pumila Mill) using a disarmed Ti-binary vector. Plant Cell Rpt. 7:658-661.

Jefferson, R.A., S.M. Burgess, and D. Hirsch. 1986. B-glucuronidase from Escherichia coli as a gene-fusion marker. Proc. Natl. Acad. Sci. USA 83:8447-8451.

Jefferson, R.A. 1987. Assaying chimeric genes in plants: The GUS gene fusion system. Plant Biol. Rpt. 5:386-405.

Kartha, K.K., R.N. Chibbar, F. Geoges, N. Leung, K. Caswell, E. Kendall, and J. Qureshi. 1989. Transient expression of chloramphenicol acetyltransferase (CAT) gene in barley cell cultures and immature embryos through microprojectile bombardment. Plant Cell Rpt. 8:429-432.

Klein, T.M., M.E. Fromm, A. Weissinger, D. Tomes, S. Schaaf, M. Sleeten, and J.C. Sanford. 1988a. Transfer of foreign genes into intact maize cells using high velocity microprojectiles. Proc. Natl. Acad. Sci. USA 85:4305-4309.

Klein, T.M., T. Gradziel, M.E. Fromm, and J.C. Sanford. 1988b. Factors influencing gene delivery into Zea mays cells by higher velocity microprojectiles. Bio/Technology 6:559-563.

Klein, T.M., E.C. Harper, Z. Svab, J.C. Sanford, M.E. Fromm, and P. Maliga. 1988c. Stable genetic transformation of intact Nicotiana cells by the particle bombardment process. Proc. Natl. Acad. Sci. USA $85: 8502-8505$

Klein, T.M., L. Kornstein, J.C. Sanford, and M.E. Fromm. 1989. Genetic transformation of maize cells by particle bombardment. Plant Physiol. 91:440-444.

Laimerda Camara Machado, M., A. daCamara Machado, V. Hanzer, H. Weiss, F. Regner, H.S. Kellner, D. Mattanovich, R. Plail, E. Knapp, B. Kalthoff, and H. Katinger. 1992. Regeneration of transgenic plants of Prunus armeniaca containing the coat protein gene of Plum Pox Virus. Plant Cell Rpt. 11:25-29.

Mante, S., R. Scorza, and J.M. Cordts. 1989. Plant regeneration from cotyledons of Prunus persica, Prunus domestica, and Prunus cerasus. Plant Cell Tissue Organ Cult. 17:1-11.

McCabe, D.E., W F. Swain, and B.J. Martinell. 1988a. Pollen-mediated plant transformation. Europe plant patent application No. 87310612. 4. 8 June 1988. Bul. 88/23.
McCabe, D.E., W.F. Swain, B.J. Martinell, and P. Christou. 1988b. Stable transformation of soybean (Glycine max) by particle acceleration. Bio/ Technology 6:923-926.

McGranahan, G.H., J. A. Driver, and W. Tuleuke. 1987. Tissue culture of Juglans, p. 261-271. In: J.M. Bonga and D.J. Durzan (eds.). Cell and tissue in forestry. vol. 3. Martinus Nijhoff, Boston.

McGranahan, G.H., C.A. Leslie, S.L. Uratsu, L.A. Martin, and A.M. Dandekar. 1988. Agrobacterium-mediated transformation of walnut somatic embryos and regeneration of transgenic plants. Bio/Technology 6:800-804.

Meyerowitz, E.M. 1987. In situ hybridization to RNA in plant tissue. Plant Mol. Biol. Rpt. 5:242-250.

Murashige, T. and F. Skoog. 1962. A revised medium for rapid growth and bioassays with tobacco tissue cultures. Physiol. Plant 15:473-497.

Russell, A.J., M.K. Roy, and J.C. Sanford. 1992. Major improvements in biolistic transformation of suspension cultured tobacco cells. In Vitro Cell Dev. Biol. 28:97-105.

Sanford, J.C., T. M. Klein, E.D. Wolf, and N. Allen. 1987. Delivery of substances into cells and tissues using a particle bombardment process. J. Particle Sci. Technol. 5:27-37.

Sanford, J.C., M.J. DeVit, J.A. Russell, F.D. Smith, R.P. Harpending, M.K. Roy, and S.A. Johnston, 1991a. An improved, helium-driven biolistic device. Technique 3:3-16.

Sanford, J.C., F.D. Smith, and J.A. Russell. 1991b. Optimizing the biolistic process for different biological applications. Methods Enzymol. 217:483-509.

Scorza, R., J.M. Cordts, and S. Mante. 1990. Long-term somatic embryo production and regeneration from embryo-derived peach callus. Proc. Intl. Symp. In Vitro Culture \& Hort. Breeding. Acta Hort. 280:183-190.

Shark, K.B., F.D. Smith, R.P. Harpending, J. Rasmussen, and J.C. Sanford. 1991. Biolistic transformation of a prokaryote, Bacillum megaterium. Applied and Environ. Microbiol. 57:480-485

Smigocki, A.C. and F.A. Hammerschlag. 1991. Regeneration of plants from peach embryo cells infected with a shooty mutant strain of Agrobacterium. J. Amer. Soc. Hort. Sci. 116:1092-1097.

Smith, F.D., P.R. Harpending, and J.C. Sanford. 1992. Biolistic transformation of prokaryotes-factors that effect biolistic transformation of very small cells. J. Gen. Microbiol. 183:239-248.

Tomes, D.T., A.K. Weissinger, M. Ross, R. Higgins, B.J. Drummond, S. Schaaf, J. Malone-Schoneberg, M. Staebell, P. Flynn, J. Anderson, and J. Howard. 1990. Transgenic tobacco plants and their progeny derived by microprojectile bombardment of tobacco leaves. Plant Mol. Biol. 14(2):261-268.

U.S. Dept. of Agriculture. 1988. Agricultural statistics 1988. U.S. GPO, Washington, D.C.

Viera, J. and J. Messing. 1987. Production of single-strand plasmid DNA. Methods Enzymol. 153:3-11.

Wang, Y.C., T.M. Klein, M.E. Fromm, J. Cao, J.C. Sanford, and R. Wu. 1988. Transient expression of foreign genes into rice, wheat and soybean cells following particle bombardment. Plant Mol. Biol. 11:433-439.

Ye, G.N., H. Daniell, and J.C. Sanford. 1990. Optimization of delivery of foreign DNA into higher-plant chloroplasts. Plant Mol. Biol. 15:809-819. 